\title{
Alteration of the food web along the Antarctic Peninsula in response to a regional warming trend
}

\author{
MARK A. MOLINE*, HERVÉ CLAUSTRE†, THOMAS K. FRAZER , OSCAR SCHOFIELD§ \\ and MARIA VERNET 9 \\ *Department of Biological Sciences, California Polytechnic State University, San Luis Obispo, CA 93407, USA, †Observatoire \\ Océanologique de Villefranche (CNRS-INSU), Laboratoire de Physique et Chimie Marines 06238, Villefranche-sur-mer, France, \\ $\ddagger$ Department of Fisheries and Aquatic Sciences, University of Florida, Gainesville, FL 32653, USA, §Coastal Ocean Observation \\ Laboratory, Institute of Marine and Coastal Sciences, Rutgers University, New Brunswick, NJ 08903, USA, -Marine Research \\ Division, Scripps Institute of Oceanography, University of California, San Diego, La Jolla, CA 92093, USA
}

\begin{abstract}
In the nearshore coastal waters along the Antarctic Peninsula, a recurrent shift in phytoplankton community structure, from diatoms to cryptophytes, has been documented. The shift was observed in consecutive years (1991-1996) during the austral summer and was correlated in time and space with glacial melt-water runoff and reduced surface water salinities. Elevated temperatures along the Peninsula will increase the extent of coastal melt-water zones and the seasonal prevalence of cryptophytes. This is significant because a change from diatoms to cryptophytes represents a marked shift in the size distribution of the phytoplankton community, which will, in turn, impact the zooplankton assemblage. Cryptophytes, because of their small size, are not grazed efficiently by Antarctic krill, a keystone species in the food web. An increase in the abundance and relative proportion of cryptophytes in coastal waters along the Peninsula will likely cause a shift in the spatial distribution of krill and may allow also for the rapid asexual proliferation of carbon poor gelatinous zooplankton, salps in particular. This scenario may account for the reported increase in the frequency of occurrence and abundance of large swarms of salps within the region. Salps are not a preferred food source for organisms that occupy higher trophic levels in the food web, specifically penguins and seals, and thus negative feedbacks to the ecology of these consumers can be anticipated as a consequence of shifts in phytoplankton community composition.

Keywords: Antarctica, climate, cryptophytes, krill, phytoplankton, salps
\end{abstract}

\section{Introduction}

Mean air temperatures along the Antarctic Peninsula have increased significantly $\left(2-3^{\circ} \mathrm{C}\right)$ over the past 50 years (King, 1994; Smith, 1994; Stark, 1994). This regional change in air temperature has long-term consequences for sea ice and ice shelf dynamics (Vaughan \& Doake, 1996; Smith \& Stammerjohn, 2001), as well as glacial melting (Ashley et al., 1994; Dierssen et al., 2002), and is likely to impact the structure and function of coastal food webs. For example, ice edge dynamics strongly influence overall phytoplankton productivity (Prézelin et al., 2000), which, in turn, fuels higher trophic levels in a relatively short food web where Antarctic Krill, Euphausia superba, is a keystone species. Most higher-level consumers depend either, directly or indirectly on this pelagic species as a food source (Laws, 1985).

Although krill are often abundant along the Antarctic Peninsula, their distributional patterns are highly variable in space and time (see Ross et al., 1996). Salpa thompsoni, another important plankton grazer in the vicinity of the Antarctic Peninsula (Nishikawa et al., 1995; Loeb et al., 1997), exhibits similar broad-scale spatial and temporal variation in abundance and distribution (Ross et al., 1996). Both species (i.e. E. superba and $S$. thompsonii) are capable of forming large aggregations, although they seldom co-occur in space (Nishikawa et al., 1995; Loeb et al., 1997; Kawaguchi 
et al., 1998; Ross et al., 1998; Hosie et al., 2000). Marked decreases in krill abundance have occurred recently in the Antarctic Peninsula region and it has been suggested that the decline is the result of poor recruitment associated with alterations in winter seaice development (Loeb et al., 1997). This observed change could be due to the decrease in the frequency of winters with extensive sea-ice development associated with the 50-year atmospheric warming trend. Alternatively, it has also been suggested that the changes in ice melting may have altered phytoplankton community composition and biomass, and may underlie the changing spatial and temporal patterns of krill and salp abundance (Hosie et al., 2000, compare with Kopczynska, 1992).

As part of the Long-Term Ecological Research Program (Smith et al., 1995), the waters near Palmer Station, Antarctica were sampled from 1991 to 1996, in part, to describe the temporal variability in the taxonomic composition of phytoplankton communities. Results are used here to comment on the shifts in the food web being observed in the coastal waters of the Antarctic Peninsula.

\section{Methods}

Discrete water samples were collected during austral spring and summer (1991-1996) at a site offshore of Palmer Station $\left(64^{\circ} 46.45^{\prime} \mathrm{S}, 64^{\circ} 03.27^{\prime} \mathrm{W}\right)$ and also during a series of shipboard transects along the Antarctic Peninsula at established stations within the LTER sampling grid (Smith et al., 1995, see also http:// www.icess.ucsb.edu/lter/overview/overview.html).

Discrete samples were collected with Niskin bottles and were analyzed for phytoplankton pigment concentrations. In-water temperature and salinity data were collected with a SBE-19 conductivity-temperaturedepth sensor (Sea-Bird Electronics Inc., Bellevue, WA, USA). Daily air temperature and initiation of glacial melt-water (as measured by absence of snow cover) were made at Palmer Station during the study period as part of a long-term database collected by the US National Science Foundation. Phytoplankton pigments were determined using high-performance liquid chromatography (HPLC) on whole-water samples (Moline \& Prézelin, 1996). Pigment data were used to estimate phytoplankton standing crop (chlorophyll $a$ ) and as chemotaxonomic markers to differentiate between algal groups using ChemTax (Mackey et al., 1996, 1998). From the class-specific accessory pigments and total chlorophyll $a$, the percent contribution of each taxonomic group to the overall biomass was calculated (Everitt et al., 1990; Moline \& Prézelin, 1996). Pigment-based estimates were verified microscopically. The dominant phytoplankton taxonomic groups highlighted in this paper were cryptophytes $(<10 \mu \mathrm{m}$ single-celled flagellated algae), diatoms (15-270 $\mu \mathrm{m}$ single-celled and chain-forming algae) and prymneseophytes (singlecelled algae that often form colonies $>200 \mu \mathrm{m}$ ). Since phytoplankton abundances were not normally distributed, a randomization ANOVA technique (100 000 randomizations, cf. Manly, 1991) was used to verify significance levels obtained from initial single classification ANOVA approach used to evaluate significant differences between phytoplankton groupings. Least square means procedures were employed as follow-up pairwise tests when distinguishing between taxonomic groupings to add robustness to the statement that these groupings in fact occupied significantly different temperature and salinity environments.

A simple model was developed to quantify the partitioning of carbon through the Antarctic food web. Total autotrophic carbon production, measured from December to January of 1991-1994, served as the model's primary input (Table 1; Moline \& Prézelin, 1996). This study also provided estimates of groupspecific production rates, which was used to partition the total production into either cryptophytes or 'other phytoplankton' (the sum of diatoms and prymnesiophytes in this study). Production from cryptophytes varied annually, with one season producing up to half the total carbon. The relative fluxes from the primary carbon pool to krill and salps were dependent on the carbon in each phytoplankton assemblage and transfer efficiencies between phytoplankton and grazers. Transfer efficiencies of carbon used in the model were mean values from previous studies relating percent retention of algae by krill based on size (Table 1; McClatchie \& Boyd, 1983; Meyer \& El-Sayed, 1983; Boyd et al., 1984; Quetin \& Ross, 1985) and on feeding studies of $S$. thompsoni (Madin \& Kremer, 1995), a principle tunicate in the Southern Ocean (Huntley et al., 1989). Partitioning of carbon to grazers was also a function of a range of previously reported krill to salp carbon ratios (Table 1; Pakhomov et al., 1994; Nishikawa et al., 1995; Loeb et al., 1997). Carbon from the grazers was directed either to higher trophic levels (Foxton, 1966; Gon \& Heemstra, 1990; Huntley et al., 1991), sedimentation or respiration (Huntley et al., 1989, 1991).

\section{Results and discussion}

Despite high interannual variability in chlorophyll $a$, a consistent and repeated pattern in phytoplankton community composition and succession was observed. Diatoms-dominated spring phytoplankton populations each year. However, there was a consistent transition from diatoms to populations of cryptophytes every 
Table 1 Model inputs used to calculate energy transfer throughout the Antarctic food web

\begin{tabular}{|c|c|c|}
\hline Model inputs & Model values & Reference \\
\hline Autotrophic carbon production $\left(\mathrm{gC} \mathrm{m}^{-2}\right)^{*}$ & $\begin{array}{l}104.63(1991-1992) \\
37.67(1992-1993) \\
32.86(1993-1994)\end{array}$ & Moline \& Prézelin (1996) \\
\hline $\begin{array}{l}\text { Cryptophyte carbon } \\
\text { Other phytoplankton carbon } \\
\text { Krill to salp carbon ratio } \\
\text { Krill to salp carbon ratio } \\
\text { Krill to salp carbon ratio }\end{array}$ & $\begin{array}{l}19-53 \% \\
47-81 \% \\
33.3,0.0641 \\
5.65 \\
0.641\end{array}$ & $\begin{array}{l}\text { Moline \& Prézelin (1996) } \\
\text { Moline \& Prézelin (1996) } \\
\text { Loeb et al. (1997) } \\
\text { Nishikawa et al. (1995) } \\
\text { Pakhomov et al. (1994) }\end{array}$ \\
\hline $\begin{array}{l}\text { Carbon transfer efficiencies } \\
\text { Cryptophytes to krill }\end{array}$ & $10 \%$ & $\begin{array}{l}\text { McClatchie \& Boyd (1983), Boyd et al. (1984), } \\
\text { Quetin \& Ross (1985) }\end{array}$ \\
\hline $\begin{array}{l}\text { Cryptophytes to salps } \\
\text { Other phytoplankton to krill }\end{array}$ & $\begin{array}{l}60 \% \\
60 \%\end{array}$ & $\begin{array}{l}\text { Madin \& Kremer (1995) } \\
\text { McClatchie \& Boyd (1983), Meyer \& El-Sayed (1983), } \\
\text { Boyd et al. (1984), Quetin \& Ross (1985) }\end{array}$ \\
\hline $\begin{array}{l}\text { Other phytoplankton to salps } \\
\text { Carbon to higher trophic levels from krill } \\
\text { Carbon to higher trophic levels from salps } \\
\text { Carbon to respiration from krill } \\
\text { Carbon to respiration from salps }\end{array}$ & $\begin{array}{l}60 \% \\
32.5 \% \\
5 \% \\
34 \% \\
14.8 \%\end{array}$ & $\begin{array}{l}\text { Madin \& Kremer (1995) } \\
\text { Huntley et al. (1991) } \\
\text { Foxton (1966), Gon \& Heemstra (1990) } \\
\text { Huntley et al. (1991) } \\
\text { Huntley et al. (1989) }\end{array}$ \\
\hline
\end{tabular}

Autotrophic carbon production was partitioned into a cryptophyte and 'other' phytoplankton pool based on measurements made from 1991 to 1994. The transfers of carbon from the primary producers to grazer pools were calculated based on grazing rates that were dependent on the size class of the algae. Carbon from primary grazers is transferred to higher trophic levels, respiration and other losses. The model incorporates both the effect of changing phytoplankton assemblage and various carbon ratios of krill to salp.

${ }^{*}$ Carbon production between December and January.

summer (Fig. 1a). The dominance of cryptophytes was coincident with the occurrence of low salinity water (Fig. 1a,b), which was associated with glacial meltwater input when air temperatures were above freezing (Fig. 1c). Cryptophyte-dominated algal biomass during melt-water events and their presence was confined to the relatively high temperature/low salinity water characteristic of the melt-water lens (Fig. 1b). While confined to surface waters, the melt-water plume often extended to depths as great as $25 \mathrm{~m}$. In contrast, diatoms and prymnesiophytes dominated the phytoplankton communities in other physiochemical domains. Shipboard transects along the Antarctic Peninsula confirmed spatially the dominance of cryptophytes in low salinity nearshore waters over the broad study region (Fig. 2). The cryptophyte-dominated waters were a significant geographic feature ranging in size from 11000 to $48000 \mathrm{~km}^{2}$ depending on the year and extended as far as a $100 \mathrm{~km}$ offshore. This dominance of cryptophytes within low salinity environments is consistent with observations from other coastal areas around the Antarctic continent (Kopczynska, 1992; McMinn \& Hodgson, 1993; Kang \& Lee, 1995; Arrigo et al., 1998; Garibotti et al., 2003) and in other ecosystems, showing physiological tolerance and even preference by cryptophytes to lower salinity waters (Prézelin \& Bozcar, 1986; Lewitus \& Caron, 1990; Lizotte \& Priscu, 1992; Claustre et al., 1997; Walsh et al., 2001). The recurrent transition from diatoms to cryptophytes represents a fundamental decrease in the size class of the phytoplankton. Bloom-forming diatoms range in size from 15 to $270 \mu \mathrm{m}$ (Kopczynska, 1992; Moline \& Prézelin, 1996), while the Antarctic cryptophytes have been measured microscopically at $8 \pm 2 \mu \mathrm{m}$ (McMinn \& Hodgson, 1993). This size decrease will impact the grazing efficiencies of different zooplankton species.

There has been a recent and significant decrease in krill abundance along the Antarctic Peninsula, which has been hypothesized to reflect poor recruitment associated with a decline in winter sea-ice development (Loeb et al., 1997). The competing hypothesis is that spatial heterogeneity in the phytoplankton is the other major determinant for the patterns of krill and salp abundance (Kopczynska, 1992; Hosie et al., 2000). Salps can efficiently graze food particles as small as $4 \mu \mathrm{m}$ in size (Harbison \& McAlister, 1979; Deibel, 1985; Harbison et al., 1986; Kremer \& Madin, 1992; Madin \& 

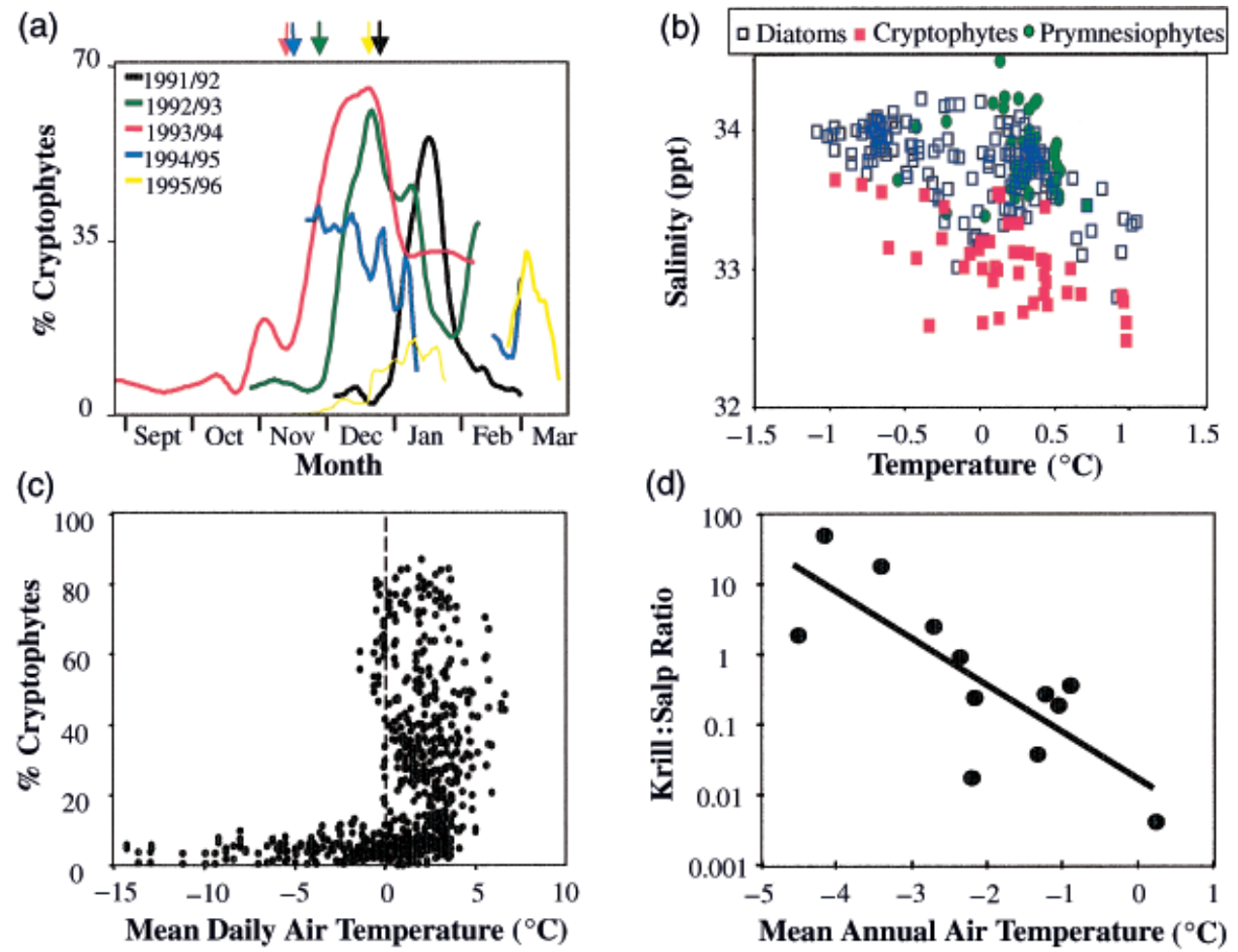

Fig. 1 (a) Seasonal changes in percent cryptophyte biomass during the spring and summer months off Palmer Station from 1991 to 1996. Arrows indicate the initiation of glacial melt-water input into the region during each year at Palmer Station. (b) Bivariate plot of temperature and salinity. Sample points indicate a $>50 \%$ contribution to the total phytoplankton biomass by diatoms, cryptophytes and prymnesiophytes at Palmer Station from 1991 to 1994. When dominant, cryptophytes occupied significantly lower salinity water than either diatoms or prymnesiophytes, which were not significantly different from each other $(P<0.001$; see Methods section for statistical approach). (c) Percent cryptophytes from (a) shown as a function of mean daily air temperature at Palmer Station for the five sampling periods $(n=696)$. (d) Relationship between mean annual air temperature $\left({ }^{\circ} \mathrm{C}\right)$ measured at Palmer Station and the annual ratios of krill to salp abundance $\left(r^{2}=0.63, n=12\right)$. Paired krill and salp data from the Antarctic Peninsula region were taken for 12 years between 1980 and 1996 (see Table 1 in Loeb et al., 1997).

Kremer, 1995), but adult krill cannot. The grazing efficiency of E. superba decreases significantly with particles $<20 \mu \mathrm{m}$ (Meyer \& El-Sayed, 1983; Boyd et al., 1984; Quetin \& Ross, 1985; Weber \& El-Sayed, 1985); therefore it is not surprising that grazing rates of krill on cryptophytes are negligible (Haberman et al., 2003).

Salps are thought to be more efficient grazers than krill on limited phytoplankton food resources. Although environmental conditions that favor salp development are not well understood, low chlorophyll concentrations and small food particles do appear to foster salp blooms (Harbison et al., 1986; Quetin et al., 1996; Ross et al., 1996 and references therein). Loeb et al. (1997) also suggests that salps are direct consumers of krill eggs and larvae (Huntley et al., 1989; Nishikawa et al., 1995), further intensifying the impact. However, segregated distribution patterns of salps and krill could alternatively indicate a low probability for the same food source (Kawaguchi et al., 1998). In areas of high primary productivity and high phytoplankton standing crops, krill are often observed, but salps are generally not. Under these conditions, the filtering apparatus of salps can become irreversibly clogged with negative consequences for growth and survival (Nishikawa et al., 1995; Quetin et al., 1996; Perissinotto \& Pakhomov, 1998a, b). Therefore, shifts from dense populations of large-celled diatoms to smaller less dense populations of cryptophytes are likely to favor the presence of salps over krill.

Increasing air temperatures documented along the Antarctic Peninsula will alter both ice shelf dynamics (Vaughan \& Doake, 1996; Smith \& Stammerjohn, 2001) and glacial melting (Ashley et al., 1994; Dierssen et al., 2002). If this warming trend continues, the proportion of cryptophyte biomass to total phytoplankton biomass would be expected to increase. This is ecologically significant and would negatively impact the coastal food webs in the Antarctic. A decrease in the phytoplankton size spectrum with warming would favor an increase in salps and would not favor krill (Fig. 

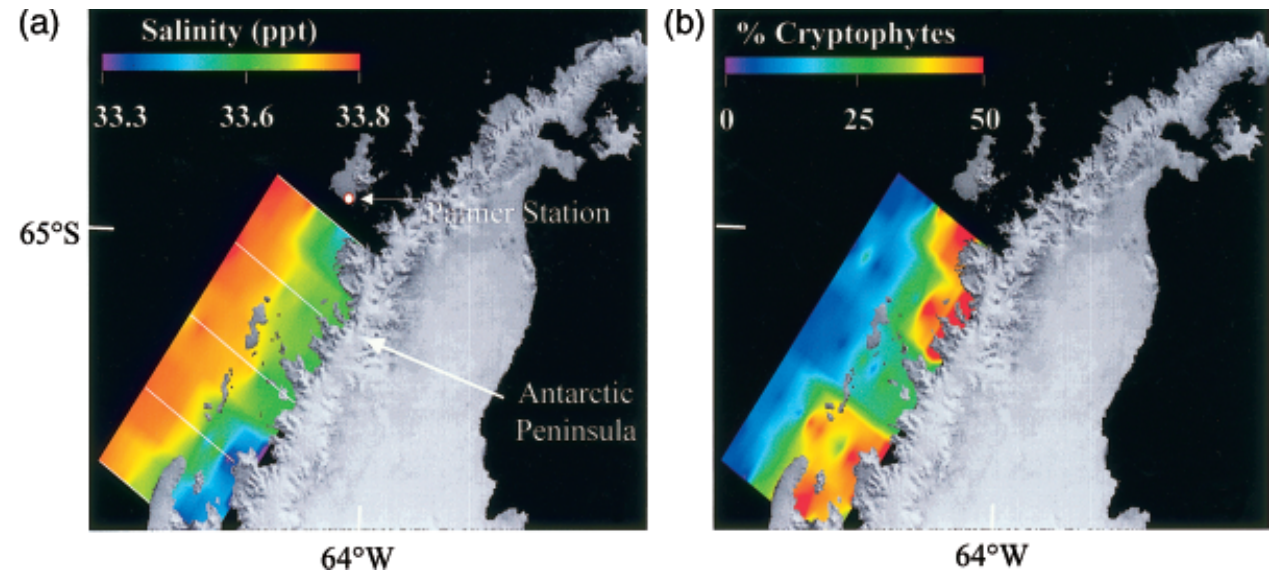

Fig. 2 (a) Surface water salinity for a survey (December 1991-January 1992) along the Antarctic Peninsula. Stations were occupied every $20 \mathrm{~km}$ along the historical LTER transect lines (white lines). (b) Concurrent integrated water column contribution of cryptophytes to total phytoplankton biomass.

Table 2 The impact of phytoplankton community composition on the percentage of carbon transferred to higher trophic levels, respired and exported to the benthos

\begin{tabular}{|c|c|c|c|}
\hline \multirow[b]{2}{*}{ Phytoplankton community } & \multicolumn{3}{|c|}{ Krill-to-salp ratio } \\
\hline & Low $(1: 15.6)$ & Medium $(1: 1)$ & High $(33: 1)$ \\
\hline \multicolumn{4}{|l|}{ Cryptophytes only } \\
\hline Carbon to higher trophic levels (\%) & 7.3 & 6 & 4.6 \\
\hline Carbon to benthos (\%) & 57.4 & 38.6 & 17.8 \\
\hline Respiration (\%) & 35.3 & 55.4 & 77.6 \\
\hline \multicolumn{4}{|l|}{ Other phytoplankton (\%) } \\
\hline Carbon to higher trophic levels (\%) & 7.7 & 9.4 & 11.1 \\
\hline Carbon to benthos (\%) & 58.0 & 43.5 & 27.3 \\
\hline Respiration (\%) & 34.3 & 47.1 & 61.6 \\
\hline
\end{tabular}

Model results based on partitioning and transfer efficiencies in Table 1.

1d). This transition is supported by modeling efforts (Walsh et al., 2001) and could occur rapidly as salps reproduce via asexual reproduction in response to favorable environmental conditions (see Alldredge, 1984). An alteration in the grazing assemblage could, in turn, lead to changes in the carbon transfer within the system. E. superba is central to the Antarctic marine food web and broad-scale shifts in its spatial distribution during summer would affect higher trophic levels, including penguins, seals and whales. As an example, the krill foraging distances for land-based species such as the Adelie penguin would necessarily increase with a subsequent negative feedback to its growth and reproduction (Fraser \& Trivelpiece, 1996). The impact on higher trophic levels may be especially significant, as cryptophyte dominance occurs during summer months when feeding activities are at a maximum (Laws, 1985). Recent reports suggest that historical penguin ranges and migration rates appear to be changing (Fraser \& Patterson, 1997; Ainley et al., 2003).

We estimated the maximal and minimal efficiencies of carbon transfer through the Antarctic Peninsula food web based on krill and salp diets of either cryptophytes or 'other phytoplankton' (assumed primarily diatoms, Table 2). The table values represent a conservative percentage of carbon from primary productivity that will either be available to higher trophic levels or will be exported out of the mixed layer. The diatomdominated waters represent the most efficient pathway for carbon transfer up the food chain. The cryptophytedominated waters are less efficient, taking into account not only grazing by salps, but also the inefficient grazing by krill on small cells and the subsequent loss of biomass to the following year's class and to higher trophic levels. A switch from diatoms to cryptophytes could lead to a $40-65 \%$ decrease in carbon transferred 
to higher trophic levels (Table 2). Similarly, the different phytoplankton assemblages result in a wide range of carbon transported to depth. Depending on the relative numbers of krill and salps, carbon transport to the benthos could fluctuate by as much as $300 \%$.

The duration and significant geographic extent of melt-water runoff (Fig. 2) is likely to increase due to the observed $2-3{ }^{\circ} \mathrm{C}$ warming trend along the Antarctic Peninsula (King, 1994; Smith, 1994; Stark, 1994; Dierssen et al., 2002). We hypothesize that an increase in melt-water input will increase the spatial and temporal extent of cryptophytes. Historical data indicate an emerging presence of cryptophytes and other phytoflagellates in low salinity coastal waters (Ferreyra \& Tomo, 1979; Whitaker, 1982; Krebs, 1983; Buma et al., 1992; Kopczynska, 1992; McMinn \& Hodgson, 1993; Kang \& Lee, 1995), corroborating this hypothesis. Observations (Loeb et al., 1997) and modeling studies (Walsh et al., 2001) also show changes in Antarctic zooplankton community composition, with an increase in salp abundance and concurrent variations in penguin migration patterns (Ainley et al., 2003). These alterations in the food web, if persistent, will ultimately impact biogeochemical cycling in Antarctic coastal waters (Walsh et al., 2001).

\section{Acknowledgements}

We thank G. Taghon, J. Gryzmski, D. M. Millie, D. IglesiasRodriguez and an anonymous reviewer for constructive comments. We acknowledge support from the Office of Polar Programs, NSF (OPP-90-11927, OPP-96-32763), the Agricultural Research Service, USDA and the Office of Naval Research (N00014-97-0767, N0014-99-0196, N00014-03-1-0341). Some data were retrieved from the Palmer LTER data archive (http:// www.icess.ucsb.edu/lter; Karen Baker, LTER data manager). The Palmer LTER data archive is supported by the Office of Polar Programs, US National Science Foundation.

\section{References}

Ainley DG, Ballard G, Emslie SD et al. (2003) Adélie penguins and environmental change. Science, 300, 429-430.

Alldredge AL (1984) The quantitative significance of gelatinous zooplankton as pelagic consumers. In: Flows of Energy and Materials in Marine (ed. Fasham MJR), pp. 407-433. Plenum Press, New York.

Arrigo KR, Robinson DH, Worthen DL et al. (1998) Bio-optical properties of the southwestern Ross Sea. Journal of Geophysical Research, 103, 21683-21695.

Ashley GM, Smith ND, Goss MC et al. (1994) Sedimentation at a subpolar tidewater glacier, Marr Ice Piedmont, Anvers Island, Antarctic Peninsula. Antarctic Journal of the United States, 29, 94-96.

Boyd CM, Heyraud M, Boyd CN (1984) Feeding of the Antarctic krill, Euphausia superba. Crustacean Biology, 4, 123-141.
Buma AGJ, Gieskes WWC, Thomsen HA (1992) Abundance of Cryptophyceae and chlorophyll-b containing organisms in the Weddell-Scotia Confluence area in the spring of 1988. Polar Biology, 12, 43-52.

Claustre H, Moline MA, Prézelin BB (1997) Sources of variability in the photosynthetic cross section for Antarctic coastal waters. Journal of Geophysical Research, 102, 25047-25060.

Deibel D (1985) Clearance rates of the salp, Thalia democratica, fed naturally occurring particles. Marine Biology, 86, 47-54.

Dierssen HM, Smith RC, Vernet M (2002) Glacial meltwater dynamics in coastal waters West of the Antarctic Peninsula. Proceedings of the National Academy of Science, 99, 1790-1795.

Everitt DA, Wright SW, Volkman JK et al. (1990) Phytoplankton community compositions in the western equatorial Pacific determined from chlorophyll and carotenoid pigment distribution. Deep-Sea Research, 37, 975-997.

Ferreyra GA, Tomo AP (1979) Variacion estational de las diatomeas planctonicas en Puerto Paraiso-I. Contribucion del Instituto Antartico Argentio, 264, 149-184.

Foxton P (1966) The distribution and life history of Salpa tompsoni Foxton with observations oa a related species, Salpa gerlachei Foxton. Discovery Report, 34, 1-116.

Fraser WR, Patterson DL (1997) Human disturbance and longterm changes in Adelie penguin populations: a natural experiment at Palmer Station, Antarctic Peninsula. In: Antarctic Communities: Species, Structure and Survival (eds Battaglia B, Valencia J, Walton DWH), pp. 445-452. Cambridge University Press, Cambridge.

Fraser WR, Trivelpiece WZ (1996) Factors controlling the distribution of seabirds: Winter-summer heterogeneity in the distribution of Adelie penguin populations. In: Foundations for Ecosystem Research in the Western Antarctic Peninsula Region (eds Ross R, Hofmann E, Quetin L), pp. 257-272. Antarctic Research Series, American Geophysical Union, Washington, DC.

Garibotti IA, Vernet M, Ferrario ME et al. (2003) Phytoplankton spatial distribution patterns along the western Antarctic Peninsula (Southern Ocean). Marine Ecology Progress Series, 261, 21-39.

Gon O, Heemstra C (1990) Fishes of the Southern Ocean. J L B Smith Institute of Ichthyology, Grahamstown.

Haberman KL, Ross RM, Quetin LB (2003) Diet of Antarctic krill (Euphausia superba Dana): II. Selective grazing in mixed phytoplankton assemblages. Journal of Experimental Marine Biology and Ecology, 283, 97-113.

Harbison GR, McAlister VL (1979) The filter-feeding rates and particle retention efficiencies of three species of Cyclosalpha (Tunicata, Thalliacca). Limnology and Oceanography, 24, 875892.

Harbison GR, McAlister VL, Gilmer RW (1986) The response of the salp, Pegea confoederata, to high levels of particulate material: starvation in the midst of plenty. Limnology and Oceanography, 31, 371-382.

Hosie GW, Schultz MB, Kitchener JA et al. (2000) Macrozooplankton community structure off East Antarctica $\left(80-150^{\circ} \mathrm{E}\right)$ during the Austral summer of 1995/1996. Deep-Sea Research, 47, 2437-2463.

Huntley ME, Lopez MDG, Karl DM (1991) Top predators in the Southern Ocean: a major leak in the biological carbon pump. Science, 253, 64-66. 
Huntley ME, Sykes PF, Marin V (1989) Biometry and trophodynamics of Salpa thompsoni foxton (Tunicata: Tahaliacea) near the Antarctic Peninsula in austral summer. Polar Biology, 10, 59-70.

Kang S-H, Lee S (1995) Antarctic phytoplankton assemblage in the western Bransfield Strait region, February 1993: composition, biomass, and mesoscale distributions. Marine Ecology Progress Series, 129, 253-267.

Kawaguchi S, Ichii T, Naganobu M et al. (1998) Do krill and salps compete? Contrary evidence from the krill fisheries. CCAMLR Science, 5, 205-216.

King JC (1994) Recent climate variability in the vicinity of the Antarctic Peninsula. International Journal of Climatology, 14, 357-369.

Kopczynska EE (1992) Dominance of microflagellates over diatoms in the Antarctic areas of deep vertical mixing and krill concentrations. Journal of Plankton Research, 14, 1031-1054.

Krebs WN (1983) Ecology of neritic marine diatoms, Arthur Harbor, Antarctica. Micropaleontology, 29, 267-297.

Kremer P, Madin LP (1992) Particle retention efficiency of salps. Journal of Plankton Research, 14, 1009-1015.

Laws RM (1985) The ecology of the Southern Ocean. American Scientist, 73, 26-40.

Lewitus AJ, Caron DA (1990) Relative effects of nitrogen or phosphorous depletion and light intensity on the pigmentation, chemical composition, and volume of Pyrenomonas salina (Cryptophyceae). Marine Ecology Progress Series, 61, 171-181.

Lizotte MP, Priscu JC (1992) Photosynthesis-irradiance relationships in phytoplankton from the physically stable water column of a perennially ice-covered lake (Lake Bonney, Antarctica). Journal of Phycology, 28, 179-185.

Loeb V, Siegel V, Holm-Hansen O et al. (1997) Effects of sea-ice extent and krill or salp dominance on the Antarctic food web. Nature, 387, 897-900.

Mackey DJ, Higgins HW, Mackey MD et al. (1998) Algal class abundances in the western equatorial Pacific: estimation from HPLC measurements of chloroplast pigments using CHEMTAX. Deep-Sea Research, 45, 1441-1468.

Mackey MD, Mackey DJ, Higgins HW et al. (1996) CHEMTAX a program for estimating class abundances from chemical markers: application to HPLC measurements of phytoplankton. Marine Ecology Progress Series, 144, 265-283.

Madin LP, Kremer P (1995) Determination of the filter-feeding rates of salps (Tunicata, Thaliacea) ICES. Journal of Marine Science, 52, 583.

Manly BFJ (1991) Randonization and Monte Carlo Methods in Biology. Chapman \& Hall, London.

McClatchie S, Boyd CM (1983) Morphological study of sieve efficiencies and manidibular surfaces in the Antarctic krill, Euphausia superba. Canandian Journal of Fisheries and Aquatic Science, 40, 955-967.

McMinn A, Hodgson D (1993) Summer phytoplankton succession in Ellis Fjord, eastern Antarctica. Journal of Plankton Research, 15, 925-938.

Meyer MA, El-Sayed SZ (1983) Grazing of Euphausia superba Dana on natural phytoplankton populations. Polar Biology, 1, 193-197.
Moline MA, Prézelin BB (1996) Palmer LTER 1991-1994: long term monitoring and analyses of physical factors regulating variability in coastal Antarctic phytoplankton biomass, in situ productivity and taxonomic composition over subseasonal, seasonal and interannual time scales. Marine Ecology Progress Series, 145, 143-160.

Nishikawa J, Naganobu M, Ichii T et al. (1995) Distribution of salps near the South Shetland Islands during austral summer, 1990-1991 with special reference to krill distribution. Polar Biology, 15, 31-39.

Pakhomov EA, Perissinoto R, McQuaid CD (1994) Comparative structure of the macro-zooplankton/micronekton communities of the Subtropical and Antarctic Polar Fronts. Marine Ecology Progress Series, 111, 155-169.

Perissinotto R, Pakhomov EA (1998a) Contribution of salps to carbon flux of marginal ice zone of the Lazarev Sea, Southern Ocean. Marine Biology, 131, 25-32.

Perissinotto R, Pakhomov EA (1998b) The trophic role of the tunicate Salpa thompsoni in the Antarctic marine ecosystem. Journal of Marine Systems, 17, 361-374.

Prézelin BB, Bozcar B (1986) Molecular basis of cell absorption and fluorescence in phytoplankton: potential applications to studies in optical oceanography. In: Progress in Phycological Research (eds Round F, Chapman D), pp. 349-465. Biopress Ltd., Bristol.

Prézelin BB, Hofmann EE, Mengelt C et al. (2000) The linkage between upper circumpolar deep water (UCDW) and phytoplankton assemblages on the west Antarctic Peninsula Continental Shelf. Journal of Marine Research, 58, 165-202.

Quetin LB, Ross RM (1985) Feeding by Antarctic krill, Euphausia superba: does size matter? In: Antarctic Nutrient Cycles and Food Webs (eds Siegfried WR, Condy PR, Laws RM), pp. 372-377. Springer-Verlag, Berlin.

Quetin LB, Ross RM, Frazer TK et al. (1996) Factors affecting distribution and abundance of zooplankton, with an emphasis on Antarctic krill, Euphausia superba. In: Foundations for Ecosystem Research in the Western Antarctic Peninsula Region (eds Ross R, Hofmann E, Quetin L), pp. 357-371. Antarctic Research Series, American Geophysical Union, Washington, DC.

Ross RM, Quetin LB, Haberman KL (1998) Interannual and seasonal variability in short-term grazing impact of Euphausia superba in nearshore and offshore waters west of the Antarctic Peninsula. Journal of Marine Systems, 17, 261-273.

Ross RM, Quetin LB, Lascara CM (1996) Distribution of Antarctic krill and dominant zooplankton west of the Antarctic Peninsula. In: Foundations for Ecosystem Research in the Western Antarctic Peninsula Region (eds Ross R, Hofmann E, Quetin L), pp. 199-217. Antarctic Research Series, American Geophysical Union, Washington, DC.

Smith RIL (1994) Vascular plants as bioindicators of regional warming in Antarctica. Oecologia, 99, 322-328.

Smith RC, Baker KS, Fraser WR et al. (1995) The Palmer LTER: a long-term ecological research program at Palmer Station, Antarctica. Oceanography, 8, 77-86.

Smith RC, Stammerjohn SE (2001) Variations of surface air temperature and sea ice extent in the Western Antarctic Peninsula (WAP) region. Annals of Glaciology, 33, 493-500.

Stark P (1994) Climate warming in the central Antarctic Peninsula area. Weather, 49, 215-220. 
Vaughan DG, Doake CSM (1996) Recent atmospheric warming and retreat of ice shelves on the Antarctic Peninsula. Nature, $379,328-331$.

Walsh JJ, Dieterle DA, Lenes J (2001) A numerical analysis of carbon dynamics of the Southern Ocean phytoplankton community: the roles of light and grazing in effecting both sequestration of atmospheric $\mathrm{CO}_{2}$ and food availability to larval krill. Deep-Sea Research, 48, 1-48.
Weber LH, El-Sayed SZ (1985) Spatial variability of phytoplankton and the distribution and abundance of krill in the Indian sector of the Southern Ocean. In: Antarctic Nutrient Cycles and Food Webs (eds Siegfried WR, Condy PR, Laws RM), pp. 283293. Springer-Verlag, Berlin.

Whitaker TM (1982) Primary production of phytoplankton off Signy Island, South Orkneys, the Antarctic. Proceedings of the Royal Society of London, 214, 169-189. 